\title{
Nucleation and Growth in Undercooled Melts of Bulk-Metallic-Glass Forming $\mathrm{Zr}_{60} \mathrm{Ni}_{25} \mathrm{Al}_{15}$ Alloy
}

\author{
Hideyuki Yasuda ${ }^{1, * 1}$, Yuki Tamura ${ }^{1}$, Tomoya Nagira ${ }^{1}$, Itsuo Ohnaka ${ }^{1, * 2}$, \\ Yoshihiko Yokoyama ${ }^{2}$ and Akihisa Inoue ${ }^{2}$ \\ ${ }^{1}$ Department of Adaptive Machine Systems, Osaka University, Osaka 565-0871, Japan \\ ${ }^{2}$ Institute of Materials Research, Tohoku University, Sendai 980-8577, Japan
}

A levitation method using alternating and static magnetic fields was used to measure nucleation and growth of the crystalline phases in melts of the bulk-metallic-glass forming $\mathrm{Zr}_{60} \mathrm{Ni}_{25} \mathrm{Al}_{15}$ alloy. For comparison, $\mathrm{Zr}_{66.7} \mathrm{Ni}_{33.3}$ and $\mathrm{Zr}_{66.5} \mathrm{Ni}_{33.2} \mathrm{Al}_{0.3}$ were also examined. Nucleation undercooling in the bulk-metallic-glass forming $\mathrm{Zr}_{60} \mathrm{Ni}_{25} \mathrm{Al}_{15}$ alloy did not depend on the cooling rate $\left(<10^{2} \mathrm{~K} / \mathrm{s}\right)$, and the maximum undercooling observed was approximately $200 \mathrm{~K}$. Recalescence was not observed in the cooling curves of the $\mathrm{Zr}_{60} \mathrm{Ni}_{25} \mathrm{Al}_{15}$ and the $\mathrm{Zr}_{66.5} \mathrm{Ni}_{33.2} \mathrm{Al}_{0.3}$ alloys. The growth velocity of the crystalline phase in the $\mathrm{Zr}_{60} \mathrm{Ni}_{25} \mathrm{Al}_{15}$ alloy was of the order of $10^{-4} \mathrm{~m} / \mathrm{s}$ even at a undercooling of $100 \mathrm{~K}$. In contrast, clear recalescence was always observed in the $\mathrm{Zr}_{66.7} \mathrm{Ni}_{33.3}$ alloy. The results showed that the addition of $\mathrm{Al}$ into the $\mathrm{Zr}-\mathrm{Ni}$ alloy significantly reduced growth velocity of the crystalline phases. The extremely low growth rate in the $\mathrm{Zr}-\mathrm{Ni}-\mathrm{Al}$ system can contribute to the high glass forming ability.

(Received August 9, 2005; Accepted November 14, 2005; Published December 15, 2005)

Keywords: levitation, undercooled melt, bulk metallic glass

\section{Introduction}

Because heterogeneous nucleation on crucible walls and contamination from crucibles can be avoided, containerless processes are useful methods to produce undercooled melts and to examine solidification in undercooled melts. In the conventional levitation method that uses an alternating magnetic field, turbulent flows and the oscillations occur in the levitated melt; therefore, it is difficult to observe solidification phenomena in which the growth velocities of crystalline phases are relatively low, since the turbulent flow can disturb the growth morphology. Recently, a new electromagnetic levitation method using alternating and static magnetic fields has been developed. ${ }^{1)}$ Superimposition of the static magnetic field on the levitated melt suppressed the oscillation and the melt flow agitated by the alternating magnetic field. As a result of the suppression, the metallic melts can be levitated without the oscillation and convection. The static levitation enables us to observe the phase transformation with rather low transformation rate. Thus, the new levitation method can be used for investigation of bulk-glassforming alloys in which crystalline phases can grow at relatively low velocities.

The nucleation behavior of the glass-forming $\mathrm{Ti}_{34} \mathrm{Zr}_{11}$ $\mathrm{Cu}_{47} \mathrm{Ni}_{8}$ alloy has been examined by electrostatic levitation. ${ }^{2)}$ Since the critical cooling rate for the $\mathrm{Ti}_{34} \mathrm{Zr}_{11} \mathrm{Cu}_{47} \mathrm{Ni}_{8}$ alloy was approximately $250 \mathrm{~K} / \mathrm{s},{ }^{3)}$ the nucleation and growth of the crystalline phases always occurred in levitated melts. The elimination of the nucleation catalysts by sufficient overheating resulted in a large degree of undercooling $\left(\Delta T_{\max }=\right.$ $220 \mathrm{~K})$. Recalescence, that is a rapid temperature increase due to the latent heat release, was always observed in the cooling curves. The observed cooling curves for $\mathrm{Ti}_{34} \mathrm{Zr}_{11^{-}}$

\footnotetext{
${ }^{* 1}$ Corresponding author, E-mail: yasuda@ams.eng.osaka-u.ac.jp

${ }^{*}$ Present address: Department of Entrepreneur Engineering, Osaka Sangyo University, Osaka 574-8530, Japan
}

$\mathrm{Cu}_{47} \mathrm{Ni}_{8}$ alloy were essentially the same as those observed in conventional metallic alloys. However, studies on the solidification in the undercooled melt for glass-forming alloys are limited.

High glass forming ability (GFA) is well recognized for Zr-based alloys. ${ }^{4-7)}$ It has been also reported that the local atomic order, such as the icosahedral order, was closely related to a high GFA. ${ }^{7-9)}$ Formation of the glass phase is directly related to suppression of nucleation and the growth of the crystalline phases. Thus, it is of interest to examine nucleation and the growth of crystalline phases in bulk-glassforming Zr-based alloys. The critical cooling rate was less than $100 \mathrm{~K} / \mathrm{s}$ for the $\mathrm{Zr}_{60} \mathrm{Ni}_{25} \mathrm{Al}_{15}$ alloy, and since typical cooling rates in the electromagnetic levitation experiments range from 10 to $100 \mathrm{~K} / \mathrm{s}$, the $\mathrm{Zr}$-based alloys are suitable for investigation of nucleation behavior by the levitation method.

This paper presents nucleation and solidification in the bulk-metallic-glass-forming $\mathrm{Zr}_{60} \mathrm{Ni}_{25} \mathrm{Al}_{15}$ alloy by electromagnetic levitation using the alternating and static magnetic fields. For comparison, nucleation and solidification of $\mathrm{Zr}_{66.7} \mathrm{Ni}_{33.3}$ and $\mathrm{Zr}_{66.5} \mathrm{Ni}_{33.2} \mathrm{Al}_{0.3}$ are also presented. On the basis of our experimental results, nucleation and solidification of the bulk-glass-forming $\mathrm{Zr}_{60} \mathrm{Ni}_{25} \mathrm{Al}_{15}$ alloy were characterized.

\section{Experiments}

The electromagnetic levitation method, ${ }^{1)}$ which uses alternating and the static magnetic fields, was used to examine nucleation and solidification behavior. Figure 1 shows the setup of the apparatus. An RF generator $(200 \mathrm{kHz}, 20 \mathrm{~kW})$ was connected to a levitation coil. A static magnetic field was imposed by using a cryogen-free superconducting magnet (maximum static magnetic field: $10 \mathrm{~T}$, bore size: $100 \mathrm{~mm}$ ).

The levitated melt was placed just above the inlet of the magnet bore so that a side view of the levitated melt could be observed by a high speed CCD camera (max $250 \mathrm{fps}$ ). The 


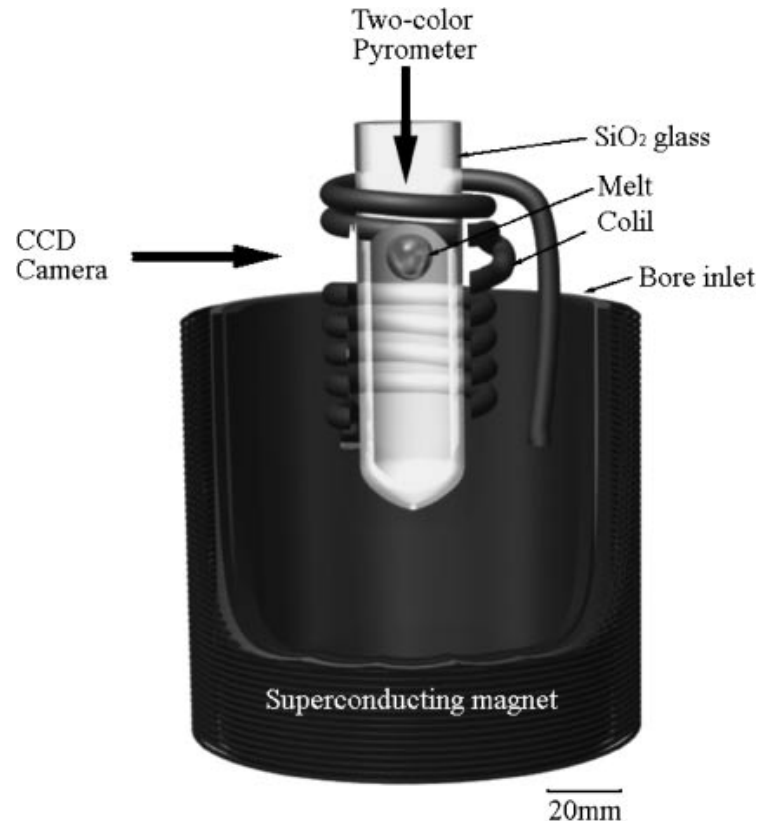

Fig. 1 Experimental setup of containerless solidification of $\mathrm{Zr}-\mathrm{Ni}-\mathrm{Al}$ alloys.

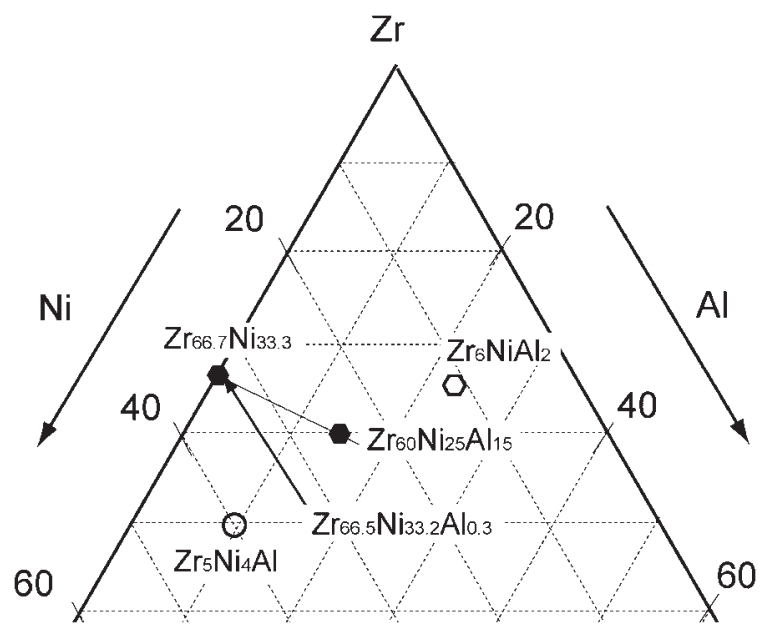

Fig. 2 Alloy compositions of the $\mathrm{Zr}-\mathrm{Ni}-\mathrm{Al}$ ternary system. The $\mathrm{Zr}_{66.5} \mathrm{Ni}_{33.2} \mathrm{Al}_{0.3}$ alloy corresponds to $99 \mathrm{~mol} \%$ (Zr66.7Ni33.3)-1 mol\% $\left(\mathrm{Zr}_{60} \mathrm{Ni}_{25} \mathrm{Al}_{15}\right)$.

growth velocity was estimated from the recorded images.

The temperature of the levitated melt was measured by a two-color pyrometer located above the levitated melt. Temperature measurements by the two-color pyrometer were calibrated by the following procedures. The specimen was melted in a high-purity $\mathrm{Al}_{2} \mathrm{O}_{3}$ crucible at the levitation position in an Ar atmosphere. Calibration of the temperature measurement was performed so that temperatures measured by the pyrometer coincided with those measured by a thermocouple inserted into the $\mathrm{Zr}-\mathrm{Ni}-\mathrm{Al}$ melts.

$\mathrm{Zr}_{60} \mathrm{Ni}_{25} \mathrm{Al}_{15}, \mathrm{Zr}_{66.7} \mathrm{Ni}_{33.3}$ and $\mathrm{Zr}_{66.5} \mathrm{Ni}_{33.2} \mathrm{Al}_{0.3}$ were made from pure $\mathrm{Zr}$, $\mathrm{Ni}$ and $\mathrm{Al}$ by an arc melting technique. Compositions of the specimens in the $\mathrm{Zr}-\mathrm{Ni}-\mathrm{Al}$ ternary system are shown in Fig. 2. The crystalline phases $\left(\mathrm{Zr}_{6} \mathrm{NiAl}_{2}\right.$ compound and $\mathrm{Zr}_{5} \mathrm{Ni}_{4} \mathrm{Al}$ compound) are also shown in the figure. Here, the $\mathrm{Zr}_{66.5} \mathrm{Ni}_{33.2} \mathrm{Al}_{0.3}$ alloy corresponds to the mixture of $98 \mathrm{~mol} \%\left(\mathrm{Zr}_{66.7} \mathrm{Ni}_{33.3}\right)-2 \mathrm{~mol} \%\left(\mathrm{Zr}_{60} \mathrm{Ni}_{25} \mathrm{Al}_{15}\right)$. Effects of the $\mathrm{Al}$ addition into the binary $\mathrm{Zr}-\mathrm{Ni}$ system on nucleation and growth were examined by comparing the results of the $\mathrm{Zr}_{66.7} \mathrm{Ni}_{33.3}$ and the $\mathrm{Zr}_{66.5} \mathrm{Ni}_{33.2} \mathrm{Al}_{0.3}$ alloys.

Typical diameters and masses of the levitated specimens were $5 \mathrm{~mm}$ and $0.8-1.0 \mathrm{~g}$, respectively. Melts were initially levitated in a pure Ar atmosphere. Overheating of the melts was approximately $200 \mathrm{~K}$. The levitated melts were cooled by $\mathrm{He}-5 \% \mathrm{H}_{2}$ gas. Cooling curves were measured by the pyrometer and cooling rates ranged from 20 to $100 \mathrm{~K} / \mathrm{s}$. Nucleation undercooling was obtained by deviation of the nucleation temperature from the liquidus temperature. The liquidus temperature $(1248 \mathrm{~K})$ of the $\mathrm{Zr}_{60} \mathrm{Ni}_{25} \mathrm{Al}_{15}$ alloy was determined by DTA analysis. Concentration of oxygen in the solidified specimens was less than $1000 \mathrm{ppm}$.

In general, temperature profile of the levitated melts consists of two stages when the melt is substantially cooled. In the first stage, growth rate of a crystal phase is sufficiently high and the undercooled droplets absorbs the latent heat. Namely, recalescence occurs in the levitated droplets. In the second stage, solidification rate is controlled by heat extraction and growth becomes slower. The recalescence clearly indicates the nucleation even in the levitated melt for conventional metallic systems.

In the case of alloy systems in which growth velocity of crystalline phases is relatively low, recalescence can be eliminated. ${ }^{10)}$ It is rather difficult to determine the nucleation temperature precisely from the cooling curves. In the present study, the nucleation temperature was defined as the temperature at which the cooling rate changed due to the latent heat. It should be noted that the nucleation can occur before the cooling rate changes, and the observed nucleation undercooling may be overestimated.

\section{Results and Discussion}

\subsection{Cooling curves and nucleation undercooling of the $\mathrm{Zr}_{60} \mathbf{N i}_{25} \mathbf{A l}_{15}$ alloy}

Figure 3 shows typical cooling curves of the $\mathrm{Zr}_{60} \mathrm{Ni}_{25} \mathrm{Al}_{15}$ alloy. The dashed lines indicate the liquidus temperature. Changes of the cooling rate were detected, and corresponded to the exothermic heat due to nucleation and growth of the crystalline phases. As shown in Fig. 3, recalescence was not observed for the $\mathrm{Zr}_{60} \mathrm{Ni}_{25} \mathrm{Al}_{15}$ alloy. Namely, heat release due to solidification did not increase the temperature of the melt up to the liquidus temperature. Thus, the heat release rate was smaller than the heat extraction rate from the melt by the cooling gas.

Figure 4 shows nucleation undercooling as a function of the cooling rate for the $\mathrm{Zr}_{60} \mathrm{Ni}_{25} \mathrm{Al}_{15}$ alloy. Nucleation undercooling ranged from 20 to $200 \mathrm{~K}$, and did not depend on the cooling rate in the present condition (cooling rate: $20-100$ $\mathrm{K} / \mathrm{s}$ ). Maximum nucleation undercooling observed was $200 \mathrm{~K}$ As mentioned above, the observed undercoolings may be higher than real nucleation undercoolings. Thus it should be mentioned that the nucleation undercooling was $200 \mathrm{~K}$ at most.

\subsection{Growth of the crystalline phases in the $\mathrm{Zr}_{60} \mathrm{Ni}_{25} \mathrm{Al}_{15}$ melt}

$\mathrm{X}$-ray diffraction indicated that the solidified specimens 


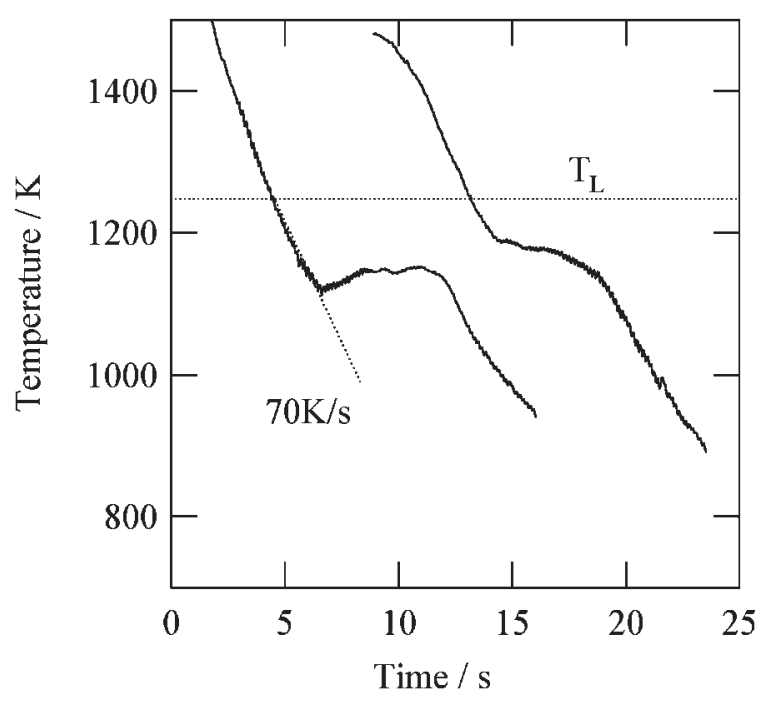

Fig. 3 Typical cooling curves of the bulk-metallic-glass forming $\mathrm{Zr}_{60} \mathrm{Ni}_{25} \mathrm{Al}_{15}$ alloy. The liquidus temperature is indicated by the dashed line.

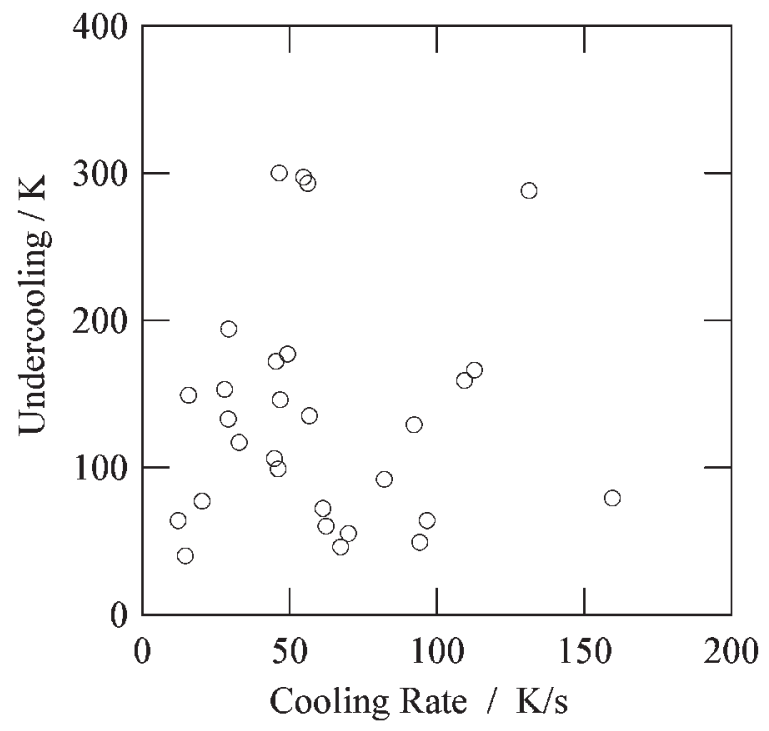

Fig. 4 Effect of cooling rate on nucleation undercooling for the $\mathrm{Zr}_{60} \mathrm{Ni}_{25} \mathrm{Al}_{15}$ alloy.

contain $\mathrm{Zr}_{5} \mathrm{Ni}_{4} \mathrm{Al}$ and $\mathrm{Zr}_{6} \mathrm{NiAl}_{2}$ phases. Here, the $\mathrm{Zr}_{5} \mathrm{Ni}_{4} \mathrm{Al}$ phase was identified from the diffraction data, ${ }^{11)}$ since the crystal structure was unknown. DSC analysis indicated that the solidified specimen contained the bulk metallic glass phase.

Figure 5 shows the solidified structure of the $\mathrm{Zr}_{60} \mathrm{Ni}_{25} \mathrm{Al}_{15}$ alloy. The $\mathrm{Zr}_{6} \mathrm{NiAl}_{2}$ phase (black), the $\mathrm{Zr}_{5} \mathrm{Ni}_{4} \mathrm{Al}$ phase (white) and the glass phase (gray) were identified in the solidified structure. The coarse $\mathrm{Zr}_{5} \mathrm{Ni}_{4} \mathrm{Al}$ crystals surrounded by the $\mathrm{Zr}_{6} \mathrm{NiAl}_{2}$ crystals, and the $\mathrm{Zr}_{6} \mathrm{NiAl}_{2}-\mathrm{Zr}_{5} \mathrm{Ni}_{4} \mathrm{Al}$ eutectic structure were observed. The solidified structure indicated that the coarse $\mathrm{Zr}_{5} \mathrm{Ni}_{4} \mathrm{Al}$ crystals grew in the undercooled melt and the solute rejection promoted growth of the $\mathrm{Zr}_{6} \mathrm{NiAl}_{2}$ crystals along the $\mathrm{Zr}_{5} \mathrm{Ni}_{4} \mathrm{Al}$ crystals. Thus, the $\mathrm{Zr}_{5} \mathrm{Ni}_{4} \mathrm{Al}$ was a primary phase in the undercooled melt.

As shown in Fig. 3, the heat release due to the latent heat

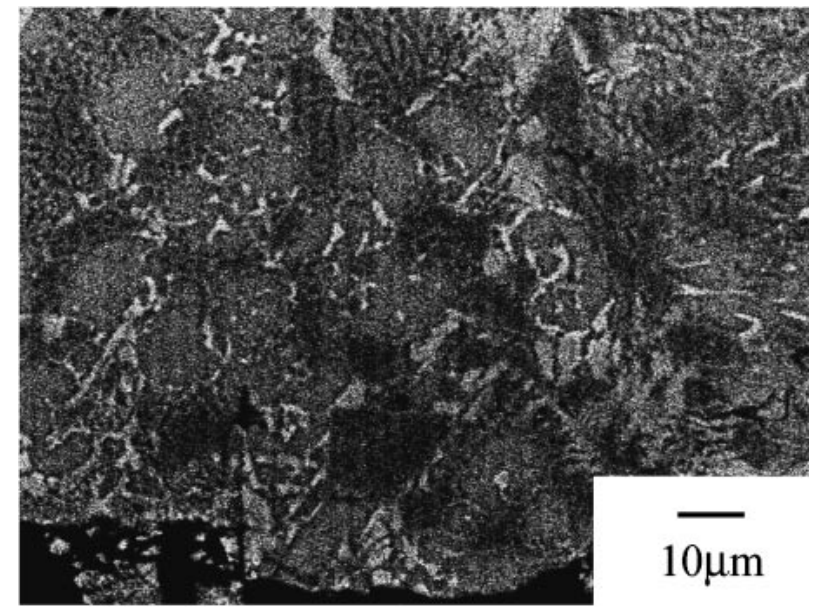

Fig. 5 Microstructure of the $\mathrm{Zr}_{60} \mathrm{Ni}_{25} \mathrm{Al}_{15}$ alloy solidified in the undercooled melt (undercooling: $120 \mathrm{~K}$ ). $\mathrm{Zr}_{6} \mathrm{NiAl}_{2}$ : black, $\mathrm{Zr}_{5} \mathrm{Ni}_{4} \mathrm{Al}$ : white and glass phase: gray.

changed the cooling rate, but did not increase the specimen temperature up to the liquidus temperature. The melt temperature decreased even after the nucleation. When the melt temperature became below the glass transition temperature, the remaining liquid phase was frozen as the glass phase.

Figure 6 shows side views of the levitated melt during the cooling procedure. The growth of the crystalline phase was detected due to the emissivity difference between the crystalline phase and the melt. Since the $\mathrm{Zr}_{5} \mathrm{Ni}_{4} \mathrm{Al}$ phase was the primary phase as shown in Fig. 5, the development of the white area on the melt surface was essentially the growth velocity of the $\mathrm{Zr}_{5} \mathrm{Ni}_{4} \mathrm{Al}$ phase. In the case of conventional solidification in which the growth velocity is high and a single nucleation event is sufficient to initiate the solidification, the growth velocity can be simply estimated from the development. On the other hand, the cooling curves observed in the $\mathrm{Zr}-\mathrm{Ni}-\mathrm{Al}$ system suggested that the growth velocity of the primary $\mathrm{Zr}_{5} \mathrm{Ni}_{4} \mathrm{Al}$ phase was low. In the case of relatively low growth velocity, copious nucleation, in which nucleation events take place one after another ahead of the growing interface, should also be considered. The estimated growth velocity becomes higher than the real growth velocity if copious nucleation occurs. It should be noted that the real growth velocity is equal to, or lower than, the growth velocity estimated from the images.

Figure 7 shows the growth velocity estimated from the recorded images as a function of the undercooling. The observe growth velocity was, at most, $10^{-3} \mathrm{~m} / \mathrm{s}$ even when the undercooling exceeded $100 \mathrm{~K}$. Furthermore, the growth velocity tended to saturate or to decrease at the high undercooling region. The tendency of the growth velocity for the $\mathrm{Zr}_{5} \mathrm{Ni}_{4} \mathrm{Al}$ phase significantly differed from that of conventional metallic alloys. For example, the growth velocity of pure Ni monotonically increased with increasing undercooling and the growth velocity was estimated to be of the order of $10^{2} \mathrm{~m} / \mathrm{s}$ in an undercooling of $150 \mathrm{~K} .^{12,13)}$ In the case of Ni-B dilute alloys, growth velocity was still of the order of $10^{0} \mathrm{~m} / \mathrm{s}$, although the addition of $\mathrm{B}$ reduced it. ${ }^{12)}$ Therefore, the present observation proved that the growth 


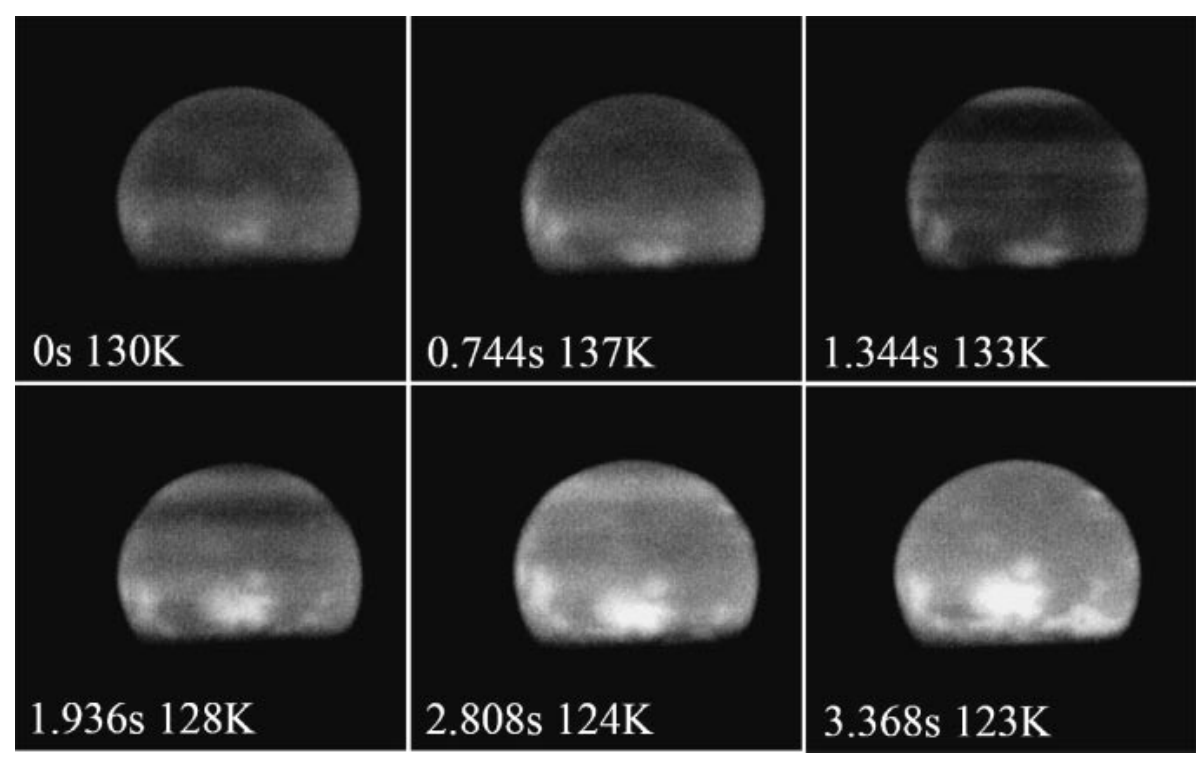

Fig. 6 Sequence of the melt surface of the $\mathrm{Zr}_{60} \mathrm{Ni}_{25} \mathrm{Al}_{15}$ alloy during the cooling procedure. The white area corresponds to the crystalline phase.

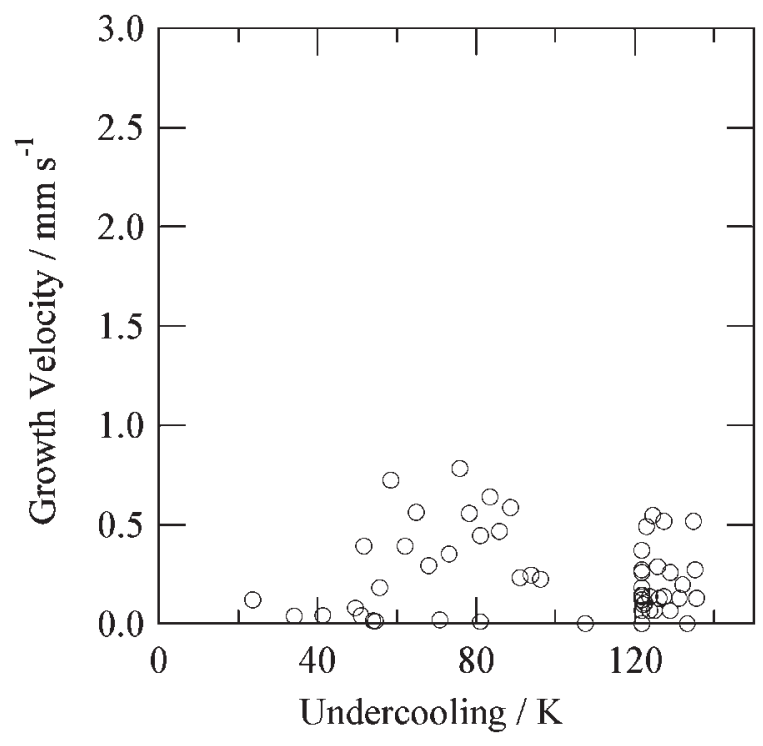

Fig. 7 Growth velocity of the $\mathrm{Zr}_{5} \mathrm{Ni}_{4} \mathrm{Al}$ compound as a function of the undercooling. Velocities were estimated by observations of the levitated melts.

velocity of the crystalline phases in the $\mathrm{Zr}_{60} \mathrm{Ni}_{25} \mathrm{Al}_{15}$ melt was extremely low compared to those in the metallic alloys.

\subsection{Solidification of the $\mathrm{Zr}_{66.7} \mathrm{Ni}_{33.3}$ and $\mathrm{Zr}_{66.5} \mathrm{Ni}_{33.2} \mathrm{Al}_{0.3}$ alloys}

Figure 8 shows a cooling curve for the $\mathrm{Zr}_{66.7} \mathrm{Ni}_{33.3}$ alloy. For the $\mathrm{Zr}_{66.7} \mathrm{Ni}_{33.3}$ binary alloy, the $\mathrm{Zr}_{2} \mathrm{Ni}$ compound (equilibrium phase, C16) nucleated in the undercooled melt. Degree of the nucleation undercooling was of the same order as that observed in the $\mathrm{Zr}_{60} \mathrm{Ni}_{25} \mathrm{Al}_{15}$ melt. Recalescence was clearly observed and the melt temperature immediately reached the melting temperature of the $\mathrm{Zr}_{2} \mathrm{Ni}$ compound. The clear recalescence showed that growth velocity of the $\mathrm{Zr}_{2} \mathrm{Ni}$ compound was much higher than that of the $\mathrm{Zr}_{5} \mathrm{Ni}_{4} \mathrm{Al}$ phase in the ternary $\mathrm{Zr}_{60} \mathrm{Ni}_{25} \mathrm{Al}_{15}$ melt.

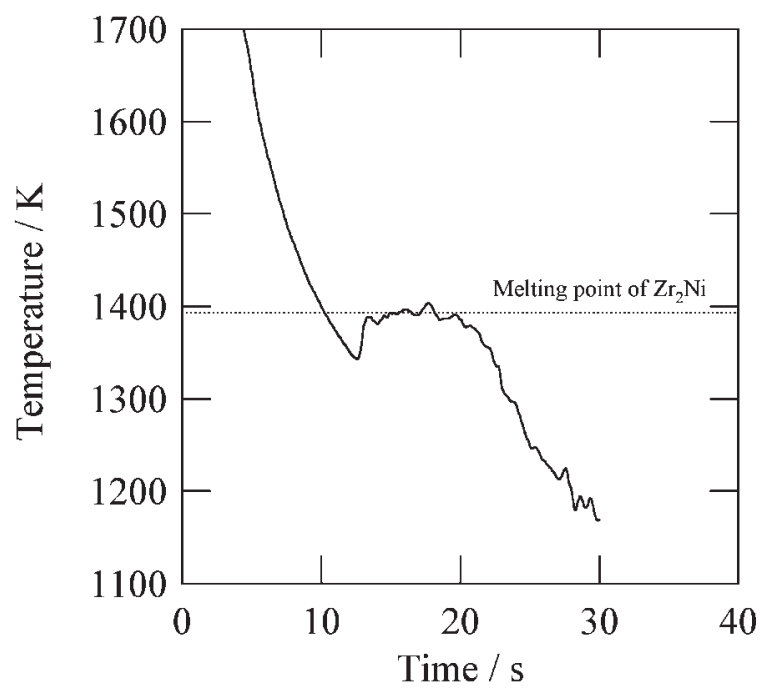

Fig. 8 Cooling curve of the $\mathrm{Zr}_{66.7} \mathrm{Ni}_{33.3}$ binary alloy.

In the solidified structure, the $\mathrm{Zr}_{2} \mathrm{Ni}-\mathrm{Zr}$ eutectic structure was observed between the $\mathrm{Zr}_{2} \mathrm{Ni}$ grains. The solute rejection also occurred in solidification of the $\mathrm{Zr}_{66.7} \mathrm{Ni}_{33.3}$ alloy. It implies that the composition of the $\mathrm{Zr}_{66.7} \mathrm{Ni}_{33.3}$ alloy was slightly higher than the congruent composition.

Figure 9 shows a typical cooling curve of the $\mathrm{Zr}_{66.5^{-}}$ $\mathrm{Ni}_{33.2} \mathrm{Al}_{0.3}$ alloy, which corresponded to a mixture of $98 \mathrm{~mol} \%\left(\mathrm{Zr}_{66.7} \mathrm{Ni}_{33.3}\right)-2 \mathrm{~mol} \%\left(\mathrm{Zr}_{60} \mathrm{Ni}_{25} \mathrm{Al}_{15}\right)$ alloy. Degree of the nucleation undercooling was almost the same as those of the $\mathrm{Zr}_{66.5} \mathrm{Ni}_{33.2} \mathrm{Al}_{0.3}$ and the $\mathrm{Zr}_{66.7} \mathrm{Ni}_{33.3}$ alloys. The cooling curves was contrast to those of the $\mathrm{Zr}_{66.7} \mathrm{Ni}_{33.3}$ alloy. Recalescence was eliminated by a small amount addition of $\mathrm{Zr}_{60} \mathrm{Ni}_{25} \mathrm{Al}_{15}$ into the $\mathrm{Zr}_{66.7} \mathrm{Ni}_{33.3}$ alloy. The growth rate of the $\mathrm{Zr}_{2} \mathrm{Ni}$ compound could become lower in the ternary system. Since the elimination of the recalescence indirectly shows reduction of the growth rate, it is required to measure the growth velocity to discuss detals of the ternary element addition. 


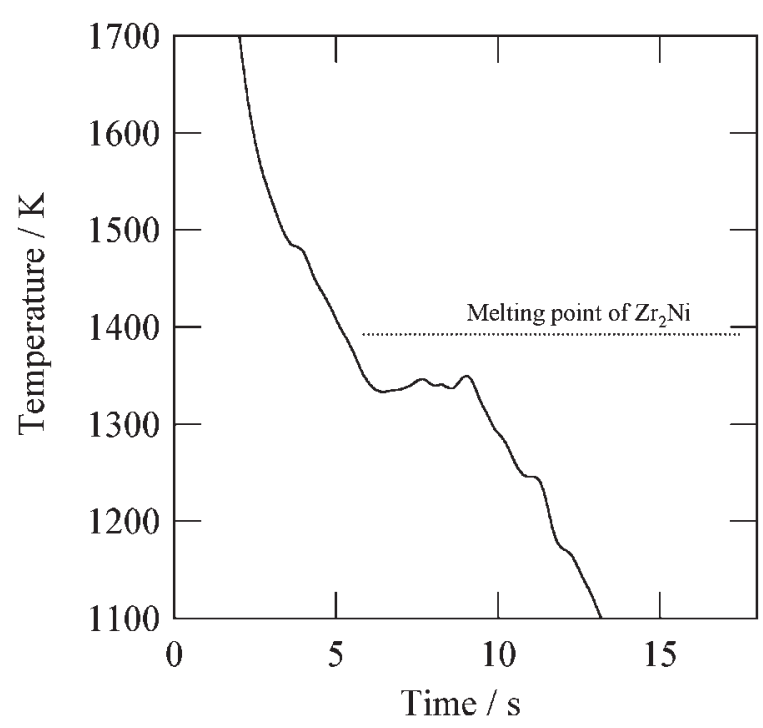

Fig. 9 Cooling curve of the $\mathrm{Zr}_{66.5} \mathrm{Ni}_{33.2} \mathrm{Al}_{0.3}$ ternary alloy.

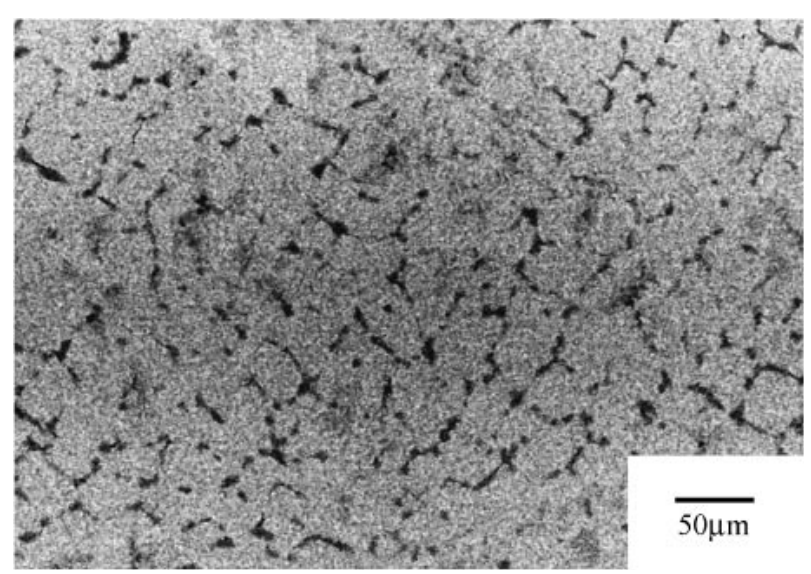

Fig. 10 Solidified structure of the $\mathrm{Zr}_{66.5} \mathrm{Ni}_{33.2} \mathrm{Al}_{0.3}$ alloy. $\mathrm{Zr}_{2} \mathrm{Ni}$ : white and Al-rich region: gray.

Figure 10 shows solidified structure of the $\mathrm{Zr}_{66.5} \mathrm{Ni}_{33.2} \mathrm{Al}_{0.3}$ alloy. Al-rich regions (black) were observed in the boundaries between the $\mathrm{Zr}_{2} \mathrm{Ni}$ grains. The segregation at the grain boundary showed that redistribution of $\mathrm{Zr}$, $\mathrm{Ni}$ and $\mathrm{Al}$ elements occurred at the solidifying front. It is generally know that addition of solutes reduces growth rate. However, the reduction did not lead to elimination of the recalescence for the Ni-based alloys. ${ }^{12)}$ The significant reduction of the growth velocity will be nature of the $\mathrm{Zr}-\mathrm{Ni}-\mathrm{Al}$ system.

It was also reported that addition of the ternary element improved the glass formation ability. ${ }^{14,15)}$ The amorphous phase was obtained only in a thin part of the Al-base binary alloys. In contrast, the amorphous state was achieved at the compositions near $\mathrm{Al}_{9} \mathrm{Fe}_{2} \mathrm{Si}_{2}$ compound. ${ }^{14)}$ The reduction of the growth velocity in the $\mathrm{Zr}-\mathrm{Ni}-\mathrm{Al}$ system and the glass phase formation are essentially explained by the previous studies. However, there is still ambiguity in understanding the reason why the small amount addition remarkably reduced the growth velocities in the $\mathrm{Zr}-\mathrm{Ni}-\mathrm{Al}$ system.

\subsection{Suppression of growth velocity in the $\mathrm{Zr}_{60} \mathrm{Ni}_{25} \mathrm{Al}_{15}$ alloy}

Formation of the glass phase has been clearly explained by considering the nucleation event during the cooling procedure. In the case that the crystalline phase exhibits sufficiently high growth velocities in the undercooled melt, the latent heat due to the solidification immediately increases the melt temperature up to the melting point or the liquidus temperature after nucleation. Solidification is completed at temperatures above the glass transition temperature, and the glass phase is produced only when nucleation does not occur.

On the other hand, the growth velocity of the crystalline phases was extremely low in the $\mathrm{Zr}-\mathrm{Ni}-\mathrm{Al}$ melt. The low growth velocity provides an alternative explanation for the formation of the bulk metallic glass phase. The solidification manner in the $\mathrm{Zr}_{60} \mathrm{Ni}_{25} \mathrm{Al}_{15}$ alloy is regarded as being a competition between growth of the $\mathrm{Zr}_{5} \mathrm{Ni}_{4} \mathrm{Al}$ compound and formation of the glass phase.

It is vague to define growth of the glass phase, since the transition from the liquid phase to the glass phase does not exhibit clear interface. Here, isothermal plane at the glass transition temperature is regarded as an interface between the liquid and the glass phases. Namely, the bulk metallic glass phase is treated like a crystalline phase (melting point is the glass transition temperature, approximately $973 \mathrm{~K}$ for $\mathrm{Zr}_{60} \mathrm{Ni}_{25} \mathrm{Al}_{15}$ ). Since solute redistribution does not occur in formation of the glass phase, the solute partition coefficient is unity. In addition, the latent heat is negligibly small. The lower melting point of "the glass phase" is a disadvantage in the competition. However, the glass phase is superior to the primary $\mathrm{Zr}_{5} \mathrm{Ni}_{4} \mathrm{Al}$ phase in terms of the solute redistribution and the latent heat release at the solidifying front.

When the moving velocity of the isothermal plane at the glass transition temperature is sufficiently higher than the growth velocity of the crystalline phase, the isothermal plane, which is regarded as the growing interface of the glass phase, overtakes the advancing front of the crystalline phase and consequently the glass phase is formed ahead of the crystalline one. It indicates that the glass phase is formed even though the crystalline phase exists in the melt. Since the observed growth velocity of the $\mathrm{Zr}_{5} \mathrm{Ni}_{4} \mathrm{Al}$ compound was of the order of $10^{-4} \mathrm{~m} / \mathrm{s}$. the critical condition is that the moving velocity of the isothermal plane at the glass transition temperature exceeds $10^{-4} \mathrm{~m} / \mathrm{s}$.

Amorphization of the surface layer in the $\mathrm{Zr}-\mathrm{Ni}-\mathrm{Al}$ alloys was examined by laser processing. ${ }^{16)}$ Thin melt layer is produced on a substrate consisting of crystalline phases, and heat transfer from the melt to the substrate rapidly cools the melt. Configuration of the glass and the crystalline phases in the laser processing is essentially the same as that in the levitated melt. Thus, it is of interest to study growth of crystalline phases in undercooled melts of the bulk-metallicglass forming alloys from fundamental and engineering aspects.

\section{Conclusions}

Nucleation and growth of the $\mathrm{Zr}_{60} \mathrm{Ni}_{25} \mathrm{Al}_{15}$, the $\mathrm{Zr}_{66.5^{-}}$ $\mathrm{Ni}_{33.2} \mathrm{Al}_{0.3}$ and the $\mathrm{Zr}_{66.7} \mathrm{Ni}_{33.3}$ alloys were examined by the levitation method. The nucleation undercooling of the 
$\mathrm{Zr}_{60} \mathrm{Ni}_{25} \mathrm{Al}_{15}$ alloy did not depend on the cooling rate $(<100 \mathrm{~K} / \mathrm{s})$, and the undercooling was $200 \mathrm{~K}$ at most. The $\mathrm{Zr}_{60} \mathrm{Ni}_{25} \mathrm{Al}_{15}$ and the $\mathrm{Zr}_{66.5} \mathrm{Ni}_{33.2} \mathrm{Al}_{0.3}$ alloys did not show clear recalescence. The observed growth velocity of the $\mathrm{Zr}_{5} \mathrm{Ni}_{4} \mathrm{Al}$ compound was in the order of $10^{-4} \mathrm{~m} / \mathrm{s}$ even when the undercooling exceeding $100 \mathrm{~K}$. In contrast, clear recalescence was observed in the $\mathrm{Zr}_{66.7} \mathrm{Ni}_{33.3}$ alloy. Thus, the addition of $\mathrm{Al}$ to the binary $\mathrm{Zr}-\mathrm{Ni}$ system remarkably reduced the growth velocities of the crystalline phases. Bulk metallic glass formation of the $\mathrm{Zr}-\mathrm{Ni}-\mathrm{Al}$ alloys was considered in terms of growth competition between the crystalline and the glass phases.

\section{Acknowledgments}

This work is supported in part by a Grant-in-Aid for Scientific Research, and the 21st Century COE Program (Ministry of Education, Culture, Sports, Science and Technology, Japan).

\section{REFERENCES}

1) H. Yasuda, I. Ohnaka, Y. Ninomiya, R. Ishii, S. Fujita and K. Kishio: J. Crystal Growth 260 (2004) 745-485.

2) C. C. Hays and W. L. Johnson: J. Non-Cryst. Solids 250-252 (1999) 596-600.

3) X. H. Lin and W. L. Johnson: Appl. Phys. Lett. 63 (1993) 2342.

4) A. Inoue, T. Zhang and T. Masumoto: Mater. Trans., JIM 31 (1990) 177.

5) A. Inoue, T. Zhang and T. Masumoto: J. Non-Cryst. Solids 156-158 (1993) 473.

6) A. L. Peker and W. L. Johnson: Appl. Phys. Lett. 63 (1993) 2342.

7) J. Saida, M. Matsushita and A. Inoue: Intermetallics, 10 (2002) 10891098.

8) E. Matsubara, T. Tamura, Y. Waseda, A. Inoue, T. Zhang and T. Masumoto: Mater. Trans., JIM 33 (1992) 873.

9) M. Imafuku, S. Sato, H. Koshiba, E. Matsubara and A. Inoue Mater. Trans., JIM 41 (2000) 1526.

10) C. G. Levi and R. Mehrabian: Metall. Trans. A 13A (1982) 221.

11) C. Li, J. Saida, M. Matsubara and A. Inoue: Mater. Lett. 44 (2000) 8086.

12) D. M. Herlach: Mater. Sci. Eng. A 226-228 (1997) 348-356.

13) K. Eckler, R. F. Cochrane, D. M. Herlach, B. Feuerbacher and M. Jurish: Phys. Rev. B 45 (1992) 5019.

14) R. O. Suzuki, Y. Komatsu, K. F. Kobayashi and P. H. Shingu: J. Mater. Sci. 18 (1983) 1195

15) D. V. Louzgune and A. Inoue: Mater. Res. Bull. 34 (1999) 1165.

16) D. Carvalho, S. Cardoso and R. Vilar: Scr. Mater. 37 (1997) 523-527. 